\title{
EFFECT OF CROP ROTATION AND TILLAGE SYSTEM ON THE WEED INFESTATION AND YIELD OF SPRING WHEAT AND ON SOIL PROPERTIES
}

\author{
WOŹNIAK, A. ${ }^{{ }^{*}-\text { SOROKA, M. }}{ }^{2}$ \\ ${ }^{1}$ Department of Herbology and Plant Cultivation Techniques, University of Life Sciences in \\ Lublin, Akademicka 13, Poland \\ ${ }^{2}$ Department of Botany, Ukrainian National Forestry University, 79057 Lviv, Ukraine \\ *Corresponding author \\ e-mail: andrzej.wozniak@up.lublin.pl \\ (Received $17^{\text {th }}$ Mar 2018; accepted $10^{\text {th }}$ May 2018)
}

\begin{abstract}
A field experiment was conducted to evaluate the effect of crop rotation and tillage system on the yield and weed infestation of spring wheat as well as on the chemical properties of soil and number of earthworms. The first experimental factor was the cropping system: 1) crop rotation A: pea - spring wheat - durum wheat, 2) crop rotation B: pea - spring barley - spring wheat, 3) cereal monoculture: spring barley - spring wheat - durum wheat, whereas the second one was the tillage system: a) conventional (CT), b) reduced (RT), and c) no-tillage (NT). Spring wheat produced a higher grain yield in crop rotation A than in crop rotation B and cereal monoculture. Its higher yield was also achieved in the CT system than in the NT and RT systems. A higher number and weight of weeds was noted in the cereal monoculture compared to crop rotations A and B. Greater weed infestation occurred also in RT and NT systems than in the CT system. In soil samples from crop rotations A and B, analyses demonstrated higher contents of organic $\mathrm{C}$ and total $\mathrm{N}$ and a lower $\mathrm{C} / \mathrm{N}$ ratio than in the cereal monoculture. The increased contents of organic $\mathrm{C}$ and total $\mathrm{N}$ in the soil were also affected by NT and RT systems, then by the CT system. Also the number of earthworms in soil $\mathrm{m}^{-2}$ was significantly higher in RT and NT than in CT system.
\end{abstract}

Keywords: cropping system, earthworms, organic carbon, soil tillage, weeds

\section{Introduction}

Crop rotation and soil tillage exert a significant influence on crop yield, weed infestation, and soil properties. Cereals cultivation in a monoculture contributes to increased weed infestation of the crop (Poggio, 2005; Woźniak and Soroka, 2015), deteriorated plant health (Hernandez-Restrepo et al., 2016), and consequently to a decreased crop yield (Nevens and Reheul, 2001; Sieling et al., 2005). The extent of yield decrease varies and depends on multiple factors including species and cultivar, weather course, fertilization, plant protection, and soil tillage (Hernanz et al., 2014). However, these factors act comprehensively, therefore have different effects on the productivity of plants (Shahzad et al., 2016). As demonstrated by De Vita et al. (2007) and by Montemurro and Maiorana (2014), in warm and arid areas higher yields of cereals are achieved in the no-till than in the conventional tillage system, whereas in moderately humid conditions better effects are obtained in the conventional than in the no-till system (Lahmar, 2010; Woźniak and Soroka, 2014).

Other outcomes of cereals cultivation in the monoculture include adverse changes in the soil including mainly loss of organic matter and organic carbon (Maillard et al., 2016), as well as suppressed enzymatic and biological activity of the soil (Kretzschmar and Monestiez, 1992; Woźniak and Kawecka-Radomska, 2016). In general, it may be 
stated that cereal monoculture leaves little diversified post-harvest residues, which leads to a reduction in the number of soil saprophytes (Olsson and Alström, 2000; Balota et al., 2004). Soil properties are also determined by its tillage systems. Many studies have demonstrated the no-till system to increase organic carbon content (West and Marland, 2002; Tabaglio et al., 2008; Ernst and Emmerling, 2009), to stabilize soil structure (Madari et al., 2005; Celik et al., 2012), to prevent soil erosion (Jordan et al., 2000), and to increase the enzymatic activity of soil and the number of earthworms in the soil (Woźniak and Kawecka-Radomska, 2016). A higher number of earthworms is indicative of the good condition of the soil environment (Lenart and Sławiński, 2010). Earthworms intensify organic matter decomposition in the soil, take part in the formation of mineral-organic colloids, regulate water-air balance in the topsoil (Laossi et al., 2010), and even indirectly alleviate the soil-borne diseases of plants induced e.g. by Gaeumannomyces graminis var. tritici (Clapperton et al., 2001).

This study aimed to evaluate the effect of crop rotation and tillage system on the yield and weed infestation of spring wheat as well as on soil properties and the number of earthworms.

\section{Material and Methods}

\section{Location and design of the experiment}

An exact field experiment was established in 2007 at the Experimental Station Uhrusk $\left(51^{\circ} 18^{\prime} 10^{\prime \prime} \mathrm{N}, 23^{\circ} 36^{\prime} 45^{\prime \prime} \mathrm{E}\right)$, belonging to the University of Life Sciences in Lublin, south-eastern Poland, whereas data presented in this manuscript was collected in the years 2015-2017. The experiment was established with the method of complete subblocks $(6 \times 25 \mathrm{~m})$ in 3 replications. The first experimental factor was the cropping system: 1) crop rotation A: pea - spring wheat - durum wheat, 2) crop rotation B: pea spring barley - spring wheat, 3) cereal monoculture: spring barley - spring wheat durum wheat, whereas the second one was the tillage system: a) conventional (CT), b) reduced (RT), and c) no-tillage (NT). In the CT system, a shallow ploughing (at a depth of 10-12 cm) and pre-winter ploughing $(25-30 \mathrm{~cm})$ were applied under all crops. In RT, both ploughing treatments were replaced by cultivation, whereas only glyphosate $(4 \mathrm{~L}$ $\mathrm{ha}^{-1}$ ) was applied in NT. A cultivator and a tillage set were used on all plots in the spring time.

\section{Soil and agroclimatic conditions}

The soil the experiment was established on was Rendzic Phaeozem (IUSS Working Group WRB, 2015) with the composition of sandy loam and with silty fraction content of $24.4 \%$ and dusty fraction content of $13.3 \%$, with a slightly alkaline $\mathrm{pH}\left(\mathrm{pH}_{\mathrm{kCL}}=7.2\right)$, high contents of available forms of phosphorus (127 mg P kg $\mathrm{m}^{-1} \mathrm{~d} . \mathrm{m}$.) and potassium (223 $\mathrm{mg} \mathrm{K} \mathrm{kg}{ }^{-1}$ ), and a medium content of magnesium (69 $\mathrm{mg} \mathrm{Mg} \mathrm{kg}^{-1}$ ).

The annual sum of atmospheric precipitation on the study area reached $620 \mathrm{~mm}$, including over $380 \mathrm{~mm}$ in the period since March till August (since the sowing to harvest of spring wheat). The highest average monthly sums of precipitation accounted for $71 \mathrm{~mm}$ in May, $73 \mathrm{~mm}$ in June, $84 \mathrm{~mm}$ in July, and $72 \mathrm{~mm}$ in August, whereas distribution of average daily air temperatures was as follows: $14.0^{\circ} \mathrm{C}$ in May, $17.1{ }^{\circ} \mathrm{C}$ in June, $19.4{ }^{\circ} \mathrm{C}$ in July, and $18.4{ }^{\circ} \mathrm{C}$ in August. 


\section{Fertilization and protection of plants}

In all study years, spring wheat and other crops cultivated in crop rotations were sown between the $1^{\text {st }}$ and $5^{\text {th }}$ of April. Spring wheat of Sonett cultivar was sown at the density of 450 seeds $\mathrm{m}^{-2}$. It was fertilized with nitrogen in a total dose of $140 \mathrm{~kg} \mathrm{~N}^{-1}$ applied in the following terms: $50 \mathrm{~kg} \mathrm{~N} \mathrm{ha}^{-1}$ before sowing, $40 \mathrm{~kg} \mathrm{~N}^{-1}$ at the tillering stage, $30 \mathrm{~kg} \mathrm{~N}^{-1}$ at the shooting stage, and $20 \mathrm{~kg} \mathrm{~N} \mathrm{ha}^{-1}$ at the earing stage. Fertilization with phosphorus and potassium was applied before wheat sowing in doses of $35 \mathrm{~kg} \mathrm{P} \mathrm{ha}^{-1}$ and $99 \mathrm{~kg} \mathrm{~K} \mathrm{ha}^{-1}$. Spring wheat was protected against fungi with the following fungicides: flusilazole + carbendazim at the 32-33 stage in Zadoks scale (Zadoks et al., 1974), and propiconazole + fenpropidin at the 53-54 stage. Weed infestation was reduced by applying a herbicide with a.i. mecoprop + MCPA + dicamba at the 23-24 stage.

\section{Yield components and statistical analysis}

The following traits were evaluated: 1) grain yield $\left(\mathrm{t} \mathrm{ha}^{-1}\right)$, 2) 1000 grain weight $(\mathrm{g})$, 3) spike number $\mathrm{m}^{-2}$ before harvest, 4) grain weight per spike (g), 5) number and air-dry weight of weeds $\left.\left(\mathrm{g} \mathrm{m}^{-2}\right), 6\right)$ species composition of weeds $\left.\left(\mathrm{m}^{-2}\right), 7\right)$ organic $\mathrm{C}$ content in the soil $\left(\mathrm{g} \mathrm{kg}^{-1}\right)$ (with Tiurin method); 8) total $\mathrm{N}$ content in the soil $\left(\mathrm{g} \mathrm{kg}^{-1}\right)$ (with Kjeldahl method), 9) $\mathrm{C} / \mathrm{N}$ ratio in soil samples, and 10) number of earthworms in the soil $\left(\mathrm{m}^{-2}\right)$. Grain was harvested using a Wintersteiger plot harvester, 1000 grain weight was determined by measuring out $2 \times 500$ grains, the number of spikes $\mathrm{m}^{-2}$ was calculated twice from the surface area of $0.5 \times 1.0 \mathrm{~m}$ of each plot, whereas grain weight per spike was established based on 40 spikes collected at random. Weed infestation was evaluated with the botanical-gravimetric method at the waxy maturity stage (stage 8384), by determining species composition of weeds and air-dry weight of weeds collected from $\mathrm{m}^{2}$ of a plot. This area was marked at random (twice) using a frame $0.5 \times 1.0 \mathrm{~m}$ in size. The air-dry weight of weeds was determined by collecting all weeds from the frame area, removing their root system, and keeping them in a well-ventilated room until constant weight has been achieved (Woźniak and Soroka, 2015). The number of earthworms $\mathrm{m}^{-2}$ was calculated in each study year at the end of May, by manual picking of the earthworms and calculating their number in 2 soil samples collected from the surface area of $0.25 \times 1.0 \mathrm{~m}$ and depth of $0.30 \mathrm{~m}$ from each plot (Woźniak and KaweckaRadomska, 2016).

Results obtained were elaborated statistically with the method of the analysis of variance (ANOVA) using Statistica PL software (StatSoft Poland). The significance of differences between mean values was evaluated with the HSD Tukey's test at $P<0.05$.

\section{Results}

\section{Grain yield and its components}

The highest grain yield was determined for spring wheat sown in crop rotation A, and a significantly lower one for wheat grown in crop rotation B (by 9.1\%) and cereal monoculture (by 23\%) - Table 1. Significant differences in grain yield occurred also between crop rotation B and cereal monoculture. Grain yield was also affected by soil tillage. Its higher value was achieved in the CT than in the NT and RT systems (by $9.8 \%$ and $19.2 \%$, respectively). It was also demonstrated that in crop rotations A and B 
a higher yield of wheat was obtained in the CT than in the RT and NT systems, whereas in cereal monoculture - in the NT and CT compared to the RT system. The evaluation of variance analysis components indicated that grain yield was affected to a greater extent by CS than by TS (Table 2).

Table 1. Effect of cropping system and tillage system on grain yield of spring wheat and its components (mean from 2015-2017)

\begin{tabular}{|c|c|c|c|c|}
\hline \multirow{2}{*}{$\begin{array}{l}\text { Cropping system } \\
\text { (CS) }\end{array}$} & \multicolumn{3}{|c|}{ Tillage system (TS) } & \multirow[t]{2}{*}{ Mean } \\
\hline & ${ }^{\mathrm{a}} \mathbf{C T}$ & RT & NT & \\
\hline \multicolumn{5}{|c|}{ Grain yield $\left(\mathrm{t} \mathrm{ha}^{-1}\right)$} \\
\hline${ }^{1} \mathrm{~A}: \mathrm{p}-\mathrm{sw}-\mathrm{dw}$ & 7.26 & 6.08 & 6.11 & 6.48 \\
\hline${ }^{2} B: p-s b-s w$ & 6.74 & 5.26 & 5.65 & 5.89 \\
\hline${ }^{3} \mathrm{C}: \mathrm{sb}-\mathrm{sw}-\mathrm{dw}$ & 5.23 & 4.17 & 5.56 & 4.99 \\
\hline Mean & 6.41 & 5.17 & 5.78 & - \\
\hline \multicolumn{5}{|c|}{$\mathrm{HSD}_{0.05}$ for $\mathrm{CS}=0.30 ; \mathrm{TS}=0.30 ; \mathrm{CS} \times \mathrm{TS}=0.72$} \\
\hline \multicolumn{5}{|c|}{1000 grain weight $(\mathrm{g})$} \\
\hline A: $p-s w-d w$ & 49.3 & 46.0 & 46.2 & 47.2 \\
\hline$B: p-s b-s w$ & 48.3 & 44.6 & 45.5 & 46.2 \\
\hline$C: s b-s w-d w$ & 43.5 & 40.3 & 44.3 & 42.7 \\
\hline Mean & 47.0 & 43.7 & 45.3 & - \\
\hline \multicolumn{5}{|c|}{$\mathrm{HSD}_{0.05}$ for $\mathrm{CS}=1.44 ; \mathrm{TS}=1.44 ; \mathrm{CS} \times \mathrm{TS}=3.43$} \\
\hline \multicolumn{5}{|c|}{ Spike number $\mathrm{m}^{-2}$} \\
\hline$A: p-s w-d w$ & 551 & 505 & 528 & 528 \\
\hline B: $p-s b-s w$ & 533 & 478 & 492 & 501 \\
\hline$C: s b-s w-d w$ & 476 & 448 & 455 & 460 \\
\hline Mean & 520 & 477 & 492 & - \\
\hline \multicolumn{5}{|c|}{$\mathrm{HSD}_{0.05}$ for $\mathrm{CS}=12.2 ; \mathrm{TS}=12.2 ; \mathrm{CS} \times \mathrm{TS}=\mathrm{ns}$} \\
\hline \multicolumn{5}{|c|}{ Grain weight per spike (g) } \\
\hline$A: p-s w-d w$ & 1.32 & 1.20 & 1.16 & 1.23 \\
\hline B: $p-s b-s w$ & 1.27 & 1.10 & 1.15 & 1.17 \\
\hline$C: s b-s w-d w$ & 1.10 & 0.93 & 1.22 & 1.08 \\
\hline Mean & 1.23 & 1.08 & 1.18 & - \\
\hline \multicolumn{5}{|c|}{$\mathrm{HSD}_{0.05}$ for $\mathrm{CR}=0.06 ; \mathrm{TS}=0.06 ; \mathrm{CR} \times \mathrm{TS}=0.15$} \\
\hline
\end{tabular}

Cropping and tillage systems affected the values of grain yield components. The 1000 grain weight was significantly higher in crop rotations A and B than in the cereal monoculture. More plump grain was also produced by wheat in the CT than in NT and RT systems. Significant differences in 1000 grain weight occurred also between NT and RT systems. Based on variance analysis components, it may be concluded that the 1000 grain weight depended to a greater extent on CS than on TS.

The number of spikes $\mathrm{m}^{-2}$ was significantly higher in crop rotation A than in crop rotation B (by 27 spikes $\mathrm{m}^{-2}$ ) and cereal monoculture (by 68 spikes $\mathrm{m}^{-2}$ ). Differences in spike number $\mathrm{m}^{-2}$ were also observed between crop rotation $\mathrm{B}$ and the cereal monoculture. A higher spike number $\mathrm{m}^{-2}$ was also demonstrated in the CT system than in the NT (by 28 spikes $\mathrm{m}^{-2}$ ) and RT (by 43 spikes $\mathrm{m}^{-2}$ ) systems. The value of this yield component was affect to a greater extent by CS than by TS. 
Grain weight per spike was significantly higher in crop rotations A and B than in the cereal monoculture. A higher grain weight per spike was also produced by wheat grown in the CT and NT systems compared to the RT system, however the evaluation of variance analysis components indicated that CS and TS had a similar effect upon this trait.

Table 2. Analysis of variance for grain yield and its components

\begin{tabular}{lcccc}
\hline Specification & Value & ${ }^{a}$ CS & TS & CS x TS \\
\hline \multirow{2}{*}{ Grain yield } & $F$ & 79.56 & 54.25 & 9.76 \\
& $P$ & $* *$ & $* *$ & $* *$ \\
\hline \multirow{2}{*}{1000 grain weight } & $F$ & 34.51 & 18.03 & 3.14 \\
& $P$ & $* *$ & $* *$ & $*$ \\
\hline \multirow{2}{*}{ Spike number $\mathrm{m}^{-2}$} & $F$ & 103.03 & 42.14 & 1.83 \\
& $P$ & $* *$ & $* *$ & $\mathrm{~ns}$ \\
\hline \multirow{2}{*}{ Grain weight per spike } & $F$ & 17.46 & 19.32 & 10.29 \\
& $P$ & $* *$ & $* *$ & $* *$ \\
\hline
\end{tabular}

${ }^{\mathrm{a}} \mathrm{CS}-$ cropping system, TS - tillage system, $* P<0.05, * * P<0.01$, ns - not significant

\section{Number, air-dry weight, and species composition of weeds}

Wheat cultivation in the cereal monoculture caused an increase in weed number $\mathrm{m}^{-2}$ (by ca. $30 \%$ ), compared to crop rotations A and B (Table 3). The number of weeds $\mathrm{m}^{-2}$ was also higher in plots cultivated in the RT system than in the CT and NT systems.

Table 3. Effect of cropping system and tillage system on the number of weeds and air-dry weight of weeds in spring wheat crop (mean from 2015-2017)

\begin{tabular}{|c|c|c|c|c|}
\hline \multirow{2}{*}{$\begin{array}{c}\text { Cropping system } \\
\text { (CS) }\end{array}$} & \multicolumn{3}{|c|}{ Tillage system (TS) } & \multirow[t]{2}{*}{ Mean } \\
\hline & ${ }^{\mathrm{a}} \mathrm{CT}$ & RT & NT & \\
\hline \multicolumn{5}{|c|}{ Number of weeds $\mathrm{m}^{-2}$} \\
\hline${ }^{1} \mathrm{~A}: \mathrm{p}-\mathrm{sw}-\mathrm{dw}$ & 12.4 & 41.1 & 26.2 & 26.6 \\
\hline${ }^{2} \mathrm{~B}: \mathrm{p}-\mathrm{sb}-\mathrm{sw}$ & 13.9 & 38.6 & 28.1 & 26.9 \\
\hline${ }^{3} \mathrm{C}: \mathrm{sb}-\mathrm{sw}-\mathrm{dw}$ & 31.3 & 52.1 & 30.5 & 38.0 \\
\hline Mean & 19.2 & 43.9 & 28.3 & - \\
\hline \multicolumn{5}{|c|}{$H S D_{0.05}$ for $\mathrm{CS}=8.8 ; \mathrm{TS}=8.8 ; \mathrm{CS} \times \mathrm{TS}=\mathrm{ns}$} \\
\hline \multicolumn{5}{|c|}{ Air-dry weight of weeds $\left(\mathrm{g} \mathrm{m}^{-2}\right)$} \\
\hline A: $p-s w-d w$ & 39.1 & 106.1 & 82.7 & 76.0 \\
\hline$B: p-s b-s w$ & 36.1 & 95.2 & 73.1 & 68.2 \\
\hline$C: s b-s w-d w$ & 84.6 & 140.8 & 82.4 & 102.6 \\
\hline Mean & 53.3 & 114.0 & 79.4 & \\
\hline
\end{tabular}

$H S D_{0.05}$ for $\mathrm{CS}=22.9 ; \mathrm{TS}=22.9 ; \mathrm{CS} \times \mathrm{TS}=\mathrm{ns}$

${ }^{1}$ Crop rotation A: $\mathrm{p}-\mathrm{sw}-\mathrm{dw}$ (pea - spring wheat - durum wheat), ${ }^{2}$ Crop rotation $\mathrm{B}: \mathrm{p}-\mathrm{sb}-\mathrm{sw}(\mathrm{pea}-$ spring barley - spring wheat), ${ }^{3}$ Cereal monoculture: $s b-s w-d w$ (spring barley - spring wheat - durum wheat), ${ }^{\mathrm{a}} \mathrm{CT}$ - conventional tillage, $\mathrm{RT}$ - reduced tillage, NT - no-tillage,

ns - not significant, $P<0.05$

Likewise, the air-dry weight of weeds was higher in the cereal monoculture than in crop rotations A and B as well as in plots cultivated in the RT than in the CT and NT systems. Greater weight was also produced by weeds in the NT than in the CT system. The evaluation of variance analysis components indicated that the number and air-dry weight of weeds were to a greater extent affected by CS than by TS (Table 4). 
Cropping and tillage systems influenced also the species composition of weeds (Table 5).

Table 4. Analysis of variance for weed infestation parameters

\begin{tabular}{lcccc}
\hline Specification & Value & ${ }^{\mathrm{a}}$ CS & TS & CS x TS \\
\hline \multirow{2}{*}{ Number of weeds } & $F$ & 7.21 & 26.63 & 1.13 \\
& $P$ & $* *$ & $* *$ & $\mathrm{~ns}$ \\
\hline \multirow{2}{*}{ Air-dry weight of weeds } & $F$ & 8.10 & 23.10 & 1.47 \\
& $P$ & $* *$ & $* *$ & $\mathrm{~ns}$ \\
\hline
\end{tabular}

${ }^{\mathrm{a}} \mathrm{CS}$ - cropping system, TS - tillage system, ${ }^{*} P<0.05, * * P<0.01, \mathrm{~ns}-$ not significant

In crop rotation A, prevailing weed species included: Papaver rhoeas and Avena fatua, on crop rotation B: Avena fatua and Fallopia convolvulus, whereas in the cereal monoculture: Avena fatua and Stellaria media. In addition, a higher number of weed species occurred in crop rotations A and B than in the cereal monoculture. A greater diversity of weed species was also observed in RT plots, a lesser one in CT plots, and the least one in NT plots.

Table 5. Dominant weed species in spring wheat per $\mathrm{m}^{2}$

\begin{tabular}{|c|c|c|c|}
\hline \multirow{2}{*}{ Weed species } & \multicolumn{3}{|c|}{ Tillage system (TS) } \\
\hline & ${ }^{\mathbf{a}} \mathbf{C T}$ & RT & NT \\
\hline \multicolumn{4}{|c|}{ Crop rotation A (Pea - spring wheat - durum wheat) } \\
\hline Papaver rhoeas L. & 2.5 & 4.3 & 3.3 \\
\hline Avena fatua $\mathrm{L}$. & 1.4 & 12.1 & 4.6 \\
\hline Stellaria media (L.) Vill. & 1.2 & 4.3 & 4.0 \\
\hline Fallopia convolvulus (L.) A. Löve & 1.2 & 1.8 & 2.2 \\
\hline Galium aparine $\mathrm{L}$. & 1.1 & 2.2 & 5.4 \\
\hline Other species & 5.0 & 16.4 & 6.7 \\
\hline Number of weed species & 19 & 24 & 16 \\
\hline \multicolumn{4}{|c|}{ Crop rotation B (Pea - spring barley - spring wheat) } \\
\hline Avena fatua $\mathrm{L}$. & 3.0 & 10.9 & 4.8 \\
\hline Fallopia convolvulus (L.) A. Löve & 2.2 & 5.6 & 2.1 \\
\hline Stellaria media (L.) Vill. & 2.0 & 5.0 & 5.3 \\
\hline Galium aparine $\mathrm{L}$. & 0.8 & 4.3 & 7.8 \\
\hline Consolida regalis Gray. & 0.8 & 3.3 & 2.2 \\
\hline Other species & 5.1 & 9.5 & 5.9 \\
\hline Number of weed species & 18 & 25 & 14 \\
\hline \multicolumn{4}{|c|}{ Cereal monoculture (Spring barley - spring wheat - durum wheat) } \\
\hline Stellaria media (L.) Vill. & 4.5 & 7.1 & 4.8 \\
\hline Avena fatua $\mathrm{L}$. & 4.3 & 12.4 & 3.7 \\
\hline Galium aparine $\mathrm{L}$. & 3.6 & 4.5 & 8.6 \\
\hline Amaranthus retroflexus $\mathrm{L}$. & 3.0 & 3.3 & 4.3 \\
\hline Galeopsis tetrahit L. & 1.2 & 4.0 & 3.9 \\
\hline Other species & 14.7 & 20.8 & 5.2 \\
\hline Number of weed species & 13 & 21 & 11 \\
\hline
\end{tabular}

${ }^{\mathrm{a}} \mathrm{CT}$ - conventional tillage, $\mathrm{RT}$ - reduced tillage, NT - no-tillage

\section{Chemical properties of soil and number of earthworms in soil}

The content of organic $\mathrm{C}$ in soil sampled from crop rotations $\mathrm{A}$ and $\mathrm{B}$ was higher by 13.3-16.3\% than in soil samples from the cereal monoculture (Table 6). Its content was 
also by $15.3-18.7 \%$ higher in soils from NT and RT plots, compared to soil samples from CT plots.

Table 6. Effect of cropping system and tillage system on chemical properties of soil and number of earthworms $(0-30 \mathrm{~cm})$

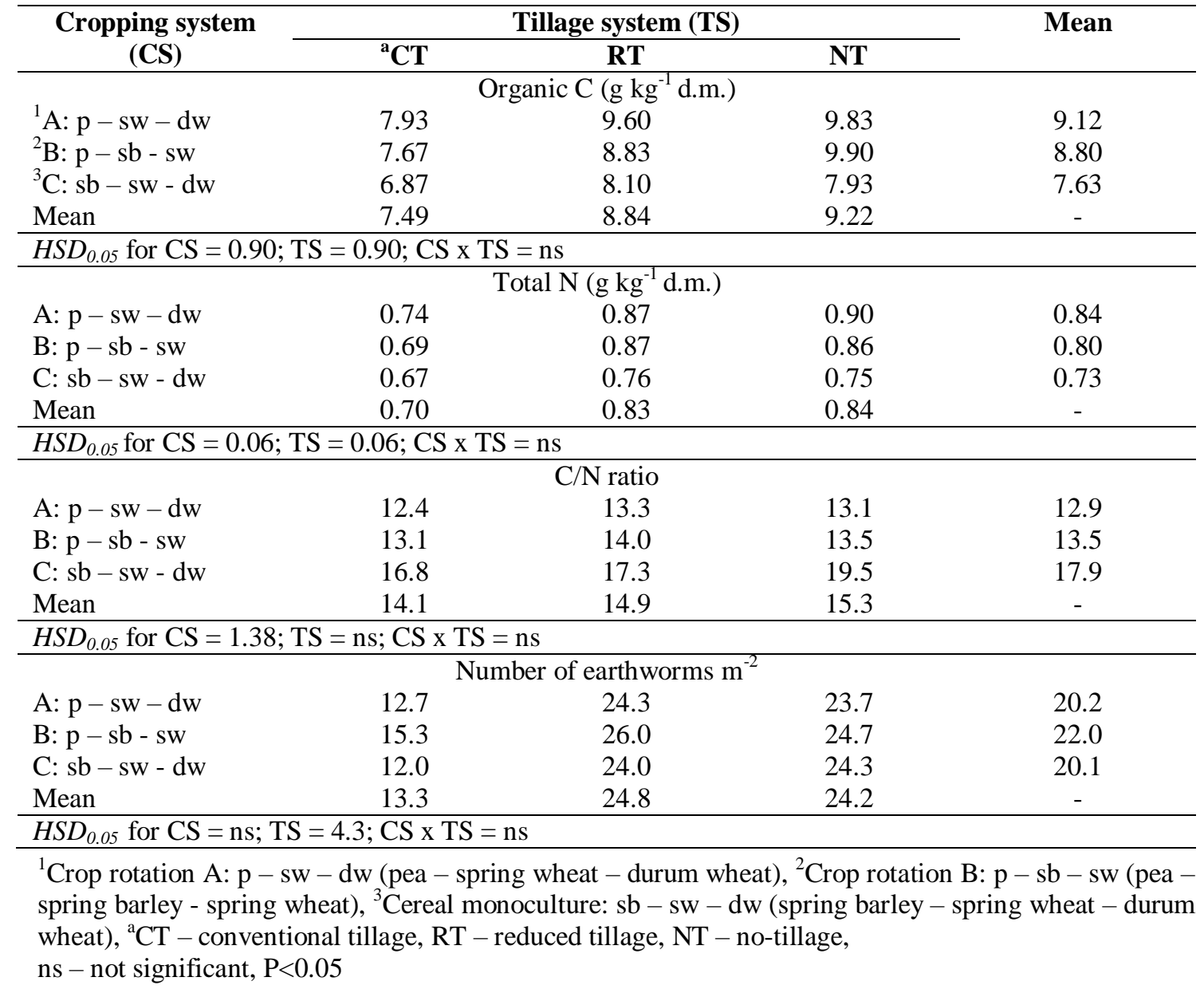

Likewise, total $\mathrm{N}$ content was higher in the soil sampled from crop rotation $\mathrm{A}$ and $\mathrm{B}$ than from the cereal monoculture as well as from NT and RT plots compared to CT plots. In crop rotations $\mathrm{A}$ and $\mathrm{B}$, the $\mathrm{C} / \mathrm{N}$ ratio was lower than in the cereal monoculture. In turn, the $\mathrm{C} / \mathrm{N}$ ratio was not affected by tillage systems, though its lower value was determined in soil samples from CT compared to NT plots. The number of earthworms in soil $\mathrm{m}^{-2}$ was significantly higher in RT and NT than in CT system. The evaluation of variance analysis components indicated that contents of organic $\mathrm{C}$ and total $\mathrm{N}$ and number of earthworms in the soil were affected to a greater extent by TS than by CS, whereas the value of $\mathrm{C} / \mathrm{N}$ ratio - by $\mathrm{CS}$ (Table 7).

Table 7. Analysis of variance for chemical properties of soil and number of earthworms

\begin{tabular}{lcccc}
\hline Specification & Value & ${ }^{\mathrm{a}}$ CS & TS & CS x TS \\
\hline \multirow{2}{*}{ Organic C } & $F$ & 9.92 & 13.43 & 0.75 \\
& $P$ & $* *$ & $* *$ & $\mathrm{~ns}$ \\
\hline \multirow{2}{*}{ Total N } & $F$ & 9.48 & 19.26 & 0.90 \\
& $P$ & $* *$ & $* *$ & $\mathrm{~ns}$ \\
\hline
\end{tabular}




\begin{tabular}{|c|c|c|c|c|}
\hline \multirow{2}{*}{$\mathrm{C} / \mathrm{N}$ ratio } & $F$ & 49.94 & 2.79 & 1.46 \\
\hline & $P$ & $* *$ & ns & ns \\
\hline \multirow{2}{*}{ Number of earthworms $\mathrm{m}^{-2}$} & $F$ & 2.12 & 6.86 & 1.03 \\
\hline & $P$ & $\mathrm{~ns}$ & $*$ & $\mathrm{~ns}$ \\
\hline
\end{tabular}

${ }^{\mathrm{a}} \mathrm{CS}$ - cropping system, TS - tillage system, $* P<0.05 ; * * P<0.01$; ns - not significant

\section{Discussion}

The reduced grain yield in the monoculture results from increased weed infestation (Woźniak and Soroka, 2015; Shahzad et al., 2016) and from crop infestation with fungal diseases, mainly these of stalk base and roots (Hernandez-Restrepo et al., 2016). In addition, some adverse changes occur in the soil under cereal monoculture including especially decreased contents of organic matter and organic C (Maillard et al., 2016), suppressed enzymatic activity of soil (Woźniak and Kawecka-Radomska, 2016), but also a reduced number of earthworms (Kretzschmar and Monestiez, 1992; Laossi et al., 2010). It may be speculated that this is due to little diversified post-harvest residues left from this type of cultivation, which leads to reduced numbers of soil saprophytes and increased counts of soil pathogens (Olsson and Alström, 2000; Balota et al. 2004). In this context, interesting findings are provided by a work of Clapperton et al. (2001) on the role of earthworm in the indirect reduction of soil-borne diseases of plants induced by Gaeumannomyces graminis. In our experiment, a higher number of earthworms in soil $\mathrm{m}^{-2}$ was determined in RT and NT than in the CT system. Likewise research conducted by Maillard et al. (2016) and by Nevens and Reheul (2001), our study showed a decrease in contents of organic $\mathrm{C}$ and total $\mathrm{N}$ in the soil sampled from the cereal monoculture, which consequently caused a less favorable $\mathrm{C} / \mathrm{N}$ ratio than in crop rotations $\mathrm{A}$ and $\mathrm{B}$. The higher contents of organic $\mathrm{C}$ and total $\mathrm{N}$ were also found in soil samples from NT and RT plots compared to CT plots. Similarly to findings reported by Poggio (2005), Shahzad et al. (2016), and by Woźniak and Soroka (2015), wheat cultivation in the monoculture resulted in increased weed infestation of the crop, i.e. weed number increase by ca. $30 \%$ and weed weight increase by over $33 \%$, compared to crop rotations. As a result, grain yield of spring wheat grown in the monoculture was lower than in crop rotations. The reduction in yield was due to a lower number of spikes $\mathrm{m}^{-2}$, a lower grain weight per spike, and a lower 1000 grain weight than in crop rotations. Higher wheat grain yields were also obtained in the CT system than in the NT and RT systems, which also resulted from higher values of yield components in this system of soil tillage.

\section{Conclusion}

To recapitulate, cultivation of spring wheat in the cereal monoculture led to unbeneficial changes in soil properties including mainly decreased contents of organic $\mathrm{C}$ and total N. Spring wheat cultivation in the cereal monoculture resulted also in a significant increase in the number and air-dry weight of weeds, compared to crop rotations. Soil properties were also influenced by its tillage system. In soil sampled from RT and NT plots analyses demonstrated higher contents of organic C and total N, and the number of earthworms in soil $\mathrm{m}^{-2}$, compared to CT plots. In turn, wheat cultivation in RT and NT systems caused a significant increase in the number and weight of weeds compared to the CT system. In a consequence, spring wheat grown in the cereal 
monoculture produced a significantly lower grain yield than in crop rotation A and B. Yield decrease resulted from a lower number of spikes $\mathrm{m}^{-2}$, lower grain weight per spike, and a lower 1000 grain weight than in the crop rotations. The higher yield of wheat was also demonstrated in the CT than in the NT and RT systems, which was due to higher values of yield components in this system of soil tillage.

\section{REFERENCES}

[1] Balota, E. L., Kanashiro, M, Filho, A. C., Andrade, D. S., Dick, R. P. (2004): Soil enzyme activities under long-term tillage and crop rotation systems in subtropical agroecosystems. - Brazilian Journal of Microbiology 35: 300-306.

[2] Celik, I., Turgut, M. M., Acir, N. (2012): Crop rotation and tillage effects on selected soil physical properties of a Typic Haploxerert in an irrigated semi-arid Mediterranean region. - International Journal Plant Production 6: 457-480.

[3] Clapperton, M. J., Lee, N. O., Binet, F., Conner, R. L. (2001): Earthworms indirectly reduce the effects of take-all (Gaeumannomyces graminis var. Tritici) on soft white spring wheat (Triticum aestivum cv. Fielder). - Soil Biology and Biochemistry 33: 15311538.

[4] De Vita, P., Di Paolo, E., Fecondo, G., Di Fonzo, N., Pisante, M. (2007): No-tillage and conventional tillage effects on durum wheat yield, grain quality, and soil moisture content in Southern Italy. - Soil and Tillage Research 92: 69-78.

[5] Ernst, G., Emmerling, Ch. (2009): Impact of five different tillage systems on soil organic carbon content and the density, biomas, and community compositin of earthworms after a ten year period. - European Journal of Soil Biology 45: 247-251.

[6] Hernandez-Restrepo, M., Groenewald, J. Z., Elliott, M. L., Canning, G., McMillan, V. E., Crous, P. W. (2016): Take-all or nothing. - Studies in Mycology 83: 19-48.

[7] Hernanz, J. L., Sánchez-Girón, V., Navarrete, L., Sánchez, M. J. (2014): Long-term (1983-2012) assessment of three tillage systems on the energy use efficiency, crop production and seeding emergence in a rain fed cereal monoculture in semiarid conditions in central Spain. - Field Crops Research 166: 26-37.

[8] IUSS Working Group WRB (2015): World Reference Base for Soil Resources 2014, update 2015. International soil classification system for naming soils and creating legends for soil maps. World Soil Resources Reports No. 106. FAO, Rome.

[9] Jordan, V. W., Leake, A. R., Ogilvy, S. E. (2000): Agronomic and environmental implications of soil management practices in integrated farming systems. - Aspects of Applied Biology 62: 61-66.

[10] Kretzschmar, A., Monestiez, P. (1992): Physical control of soil biological activity due endogenic earthworm behaviour. - Soil Biology and Biochemistry 24: 1609-1614.

[11] Lahmar, R. (2010): Adoption of conservation agriculture in Europe lesson of the KASSA project. - Land Use Policy 27: 4-10.

[12] Laossi, K. R., Ginot, A., Noguera, D. C., Blouin, M., Barot, S. (2010): Earthworm effects on plant growth do not necessarily decrease with soil fertility. - Plant and Soil 328: 109118.

[13] Lenart, S., Sławiński, P. (2010): Selected soil properties and the occurrence of earthworms under the conditions of direct sowing and mouldboard ploughing. Fragmenta Agronomica 24: 86-93.

[14] Madari, B., Machado, P. L. O. A., Torres, E., de Andrade, A. G., Valencia, L. I. O. (2005): No tillage and crop rotation effects on soil aggregation and organic carbon in a Rhodic Ferralsol from southern Brazil. - Soil and Tillage Research 80: 185-200.

[15] Maillard, É., Angers, D. A., Chantigny, M., Lafond, J., Pageau, D., Rochette, P., Lévesque, G., Leclerc, M. L., Parent, L. É. (2016): Greater accumulation of soil organic 
carbon after liquid dairy manure application under cereal-forage rotation than cereal monoculture. - Agriculture, Ecosystems and Environment 233: 171-178.

[16] Montemurro, F., Maiorana, M. (2014): Cropping systems, tillage and fertilization strategies for durum wheat performance and soil properties. - International Journal of Plant Production 8: 51-76.

[17] Nevens, F., Reheul, D. (2001): Crop rotation versus monoculture; yield, N yield and ear fraction of silage maize at different levels of mineral $\mathrm{N}$ fertilization. - Netherlands Journal of Agricultural Science 49: 405-425.

[18] Olsson, S., Alström, S. (2000): Characterisation of bacteria in soils under barley monoculture and crop rotation. - Soil Biology and Biochemistry 32: 1443-1451.

[19] Poggio, S. L. (2005): Structure of weed communities occurring in monoculture and intercropping of field pea and barley. - Agriculture, Ecosystems and Environment 109: $48-58$.

[20] Shahzad, M., Farooq, M., Jabran, K., Hussain, M. (2016): Impact of different crop rotations and tillage systems on weed infestation and productivity of bread wheat. - Crop Protection 89: 161-169.

[21] Sieling, K., Stahl, C., Winkelmann, C., Christen, O. (2005): Growth and yield of winter wheat in the first 3 years of a monoculture under varying $\mathrm{N}$ fertilization in NW Germany. - European Journal of Agronomy 22: 71-84.

[22] Tabaglio, V., Gavazzi, C., Menta, C. (2008): The influence of no-till, conventional tillage and nitrogen fertilization on physico-chemical and biological indicators after three years of monoculture barley. - Italian Journal of Agronomy 3: 233-240.

[23] West, T. O., Marland, G. (2002): A synthesis of carbon sequestration, carbon emissions, and net carbon flux in agriculture: Comparing tillage practices in the United States. Agriculture, Ecosystems and Environment 91: 217-232.

[24] Woźniak, A., Soroka, M. (2014): Effects of a 3-year reduced tillage on the yield and quality of grain and weed infestation of spring triticale (Triticosecale Wittmack). International Journal of Plant Production 8: 231-242.

[25] Woźniak, A., Soroka, M. (2015): Structure and weed communities in crop rotation and monoculture of cereals. - International Journal of Plant Production 9: 487-506.

[26] Woźniak, A., Kawecka-Radomska, M. (2016): Crop management effect on chemical and biological properties of soil. - International Journal of Plant Production 10: 391-401.

[27] Zadoks, J. C., Chang, T. T., Konzak, C. F. (1974): A decimal code for the growth stages of cereals. - Weed Research 1: 415-421. 